\title{
The Impact of Agro-Industrial Rice Cultivation: Case of The Challenges Facing Rice Farmers in Upper Nun Valley Development Authority (Unvda) Cameroon
}

\author{
Joseph Zambo Mooh \\ Ets Agricam, Cameroon
}

\begin{abstract}
Agriculture is considered as a potential sector to revive the Cameroonian's economy as well as it has been hailed by the Head of State in his message to the Nation as a crucial technique for the economic vision planned for the year 2035.

This project depicts the impact of Agro-industrial ${ }^{1}$ rice cultivation in Cameroon. In addition, it illustrates the challenges facing rice farmers in Upper Nun Valley Development Authority (UNVDA).

Moreover, the finding of this research will be significant for foreign direct investment in the Cameroonian's rice sector as well as important concepts in business management.

The questionnaire and measurement scale in this research are used and adapted from other studies carried out by previous researchers. Moreover, the questionnaire was handed out to participants in October 2018.

The research objective was answered. The target respondents were young adults in Cameroon. Thus, this research depicts marketing and distribution of fertilizer, irrigation and investment in water control, maintenance and agricultural equipment, support for structuring and suitable credit financing as major components to develop Agro-industrial rice cultivation in Cameroon
\end{abstract}

Keywords - Agro-industrial rice cultivation, marketing and distribution of fertilizer, irrigation and investment in water control, maintenance and agricultural equipment, support for structuring and suitable credit financing.

\section{INTRODUCTION}

$\mathrm{R}$ ice cultivation has been dated as far back as the colonial era. In this sector, since the independence in 1960, Cameroon has potentially generated better rates than most other nations. Such production depicted a tremendous evolution from 1960 to 1985. Today, rice production is in the hands of peasant sectors or small holders that produce an overwhelming $93 \%$ of total output. In terms of demands, the difference is made up by imports that continually increase.

Therefore, attention really needs to be given in order to develop rice production in Cameroon. Furthermore, Cameroon is greatly dependent on food imports to its feed its population. However, regarding trade, the degree of reliance today in Cameroon has many negative consequences like fostering monopolizing world markets as well as fostering a dependence on highly volatile, a lack of long- term national security strategy and harm domestic agricultural production that do not stand out on inexpensively produced imported foods or highly subsidized. With regards to trade, even though, its current reliance has labor forces and potential land to highly increase its food production and ultimately eliminate import dependency together. Cameroon has over $70 \%$ of the population growth crops, either staple foods or cash crops to feed home families.

Moreover, $40 \%$ of Cameroon's gross domestic product comes from agricultural production even though the reality of the current production demonstrates a small portion of what is possible. Cameroon has more than 250.000 hectares of cultivable land, but only 25.000 hectares are now exploited for agricultural production. As such, these elements depict the potential for agricultural production and development as well as investing in Agro- industrial rice in Cameroon.

Rice consumption in Cameroon has been increasingly risen at about $8 \%$ per annum, today $96 \%$ of the population in Cameroon eats rice once a week minimum. However, since then, home production has been unable to meet the demand that inefficiently leads to inefficient imports.

Moreover, it stands at about 400.000 tons early and account for $90 \%$ of the whole country's needs, showing how endowed Cameroon is with water resources and important land for food production. Therefore, imports of rice consumption have consequently aroused throughout the country. As such, this sector needs to be boosted as immediate actions are needed to increase rice production.

This research paper is therefore examined because the government has recently expressed concern about the need to restructure the rice sector, thus, in the framework of income generation and diversification, this sector is seen potential crop for the nation to get rid of hunger as well as generating income for the poor and by 2016, be certain to achieve the millennium development goal so as to reduce poverty. Procedure for Paper Submission.

\section{SECTION 1}

(UNVDA's industry outlook in Ndop Plain)

Testar

he project of Ndop rice has started since 1970 through the establishment of the mission of rice production that was converted in 1978 into a development authority known as Upper Nun Valley Development Authority (UNVDA) that is parasternal charged with changing the marshy areas and swamps areas

${ }^{1}$ it refers to the large- scale production, packaging and processing of food using new methods and modern equipment. [30] 
of Ndop plain to an irrigated rice project. However, majority of rice farmers so far in the plain is small holder's producers that employ practices of intensive labor rather than the mechanized rice farming set out by the project. [1]

In 2012, MINADER, disclosed that UNVDA has set out 2500 hectares for rice production with 8500 farmers. Thus, it translates to less than 0.4 hectare per farmer as well as to less than $25 \%$ of the surface ear-marked for rice farming. Furthermore, merely 1800 of the 2500 hectares set out are under cultivation. Moreover, the developed rice farms that lack infrastructure like a well a developed irrigation system and access roads. Thus, UNVDA- developed farms are irrigated with water from numerous rivers and streams from the Bamenjim dam.

\section{A. Significance of the study}

Analysis and multiple concepts of the impact of Agro - industrial rice cultivation in Cameroon, case study of the challenges facing rice farmers in UNVDA, Cameroon are made and important conclusions are also indicated in the process. As such, the analysis of the challenges and successes facing rice farmers in UNVDA, Cameroon will be taken into consideration as well as the implementation of concepts and suggested general knowledge based on rice farmers in UNVDA, Cameroon will be indicated accordingly by suppliers and companies in the Agro industry sector.

\section{B. Research question}

- How do marketing and distribution of fertilizer affect Agro - industrial rice cultivation in UNVDA, Cameroon?

- How do irrigation and investment in water control affect Agro - industrial rice cultivation UNVDA, Cameroon?

- How maintenance and agricultural equipment's effects affect Agro - industrial rice cultivation in UNVDA, Cameroon?

- How support for financing affects Agro - industrial cultivation in UNVDA Cameroon?

- How suitable credit financing affects Agro - industrial rice cultivation in UNVDA Cameroon?

\section{Research objectives}

- To analyze how marketing and distribution of fertilizer affect Agro - industrial rice cultivation in UNVDA, Cameroon.

- To illustrate how irrigation and investment in water control affect Agro - industrial rice cultivation UNVDA, Cameroon.

- To determine how maintenance and agricultural equipment affect Agro-industrial rice cultivation in UNVDA, Cameroon.

- To elaborate how support for structuring the effects of harvesting affect Agro - industrial cultivation in UNVDA Cameroon.

- To investigate how suitable credit financing affects Agro -industrial rice cultivation in UNVDA Cameroon.

\section{Research Framework}

FACTORS/CAUSES

DEPENDENT

VARIABLE

\begin{tabular}{|c|c|c|}
\hline • & $\begin{array}{l}\text { Marketing and distribution } \\
\text { of fertilizer }\end{array}$ & \\
\hline • & $\begin{array}{l}\text { Irrigation and investment in } \\
\text { water control }\end{array}$ & \\
\hline • & $\begin{array}{l}\text { Maintenance and } \\
\text { agricultural Equipment }\end{array}$ & $\begin{array}{l}\text { Agro - industrial rice } \\
\text { cultivation }\end{array}$ \\
\hline$\bullet$ & Support for structuring & \\
\hline - & Suitable credit financing & \\
\hline
\end{tabular}

Table 1: Research framework

(It describes the key factors to invest in Cameroon in the Agroindustrial rice sector).

\section{Source: Author}

\section{SECTION 2}

\section{A. Literature review}

1) Rice production-tractors to develop Yields in UNVDA (Cameroon)

I $\mathrm{N}$ order to systematically put an end to the importation of rice,

the Upper Nun Valley Development Authority is to put more rice on the table at good prices. On August 14, 2012, it emerged from the 42nd board meeting of Agro industry that resources lately made available by government inspires dreams towards exploiting the 15.000 hectares of land earmarked for rice farms in the neighborhood and Ndop plain. . [2]

The meeting of mid -term evaluation has revealed that the Upper Nun Valley Development Authority loan scheme in 2010 conceived to delegate farmers with chemicals and inputs has therefore increased production from 3-5 metric tons of rice per hectare.

Production Head, according to Cameroon Tribune, Azomba Abena Simon told that "the Agro industry is actually at the end of transformation from nursery to rice fields. However, the Upper Nun Valley Development Authority is committed to working with some 12.000 farmers that produce 'tox 3145'" and the long grain rice around 3000 hectares of land"'. Thus, the machines that were bought from funds from government have also facilitated production with chemicals at low cost and effective fertilizers [3]. As such, farmers have the privilege to hire Upper Nun Valley Development Authority's tractors at moderate cost for land preparation, meanwhile the Agro industry sells improved seeds to farmers.

The Construction Department and the president of Head Land Development Francis Fonayi Waindim said "the new acquisition of heavy-duty equipment is helping serious matters in roads works". It therefore includes compactor, a grader, wheel loader, and a hydraulics excavator. However, awaited is a Low Loader and a bulldozer to ease the transportation of equipment. Moreover, it is against the backdrop that Upper Nun Valley Development Authority is actually on song with the rehabilitation of some hectares of land. 
In Cameroon, the importation of rice is still regarded as an ongoing phenomenon. This is obvious as the demand for consumption in the nation is higher than what is actually produced in the farms and local markets. Thus, sources from the Cameroon customs department puts the figures of rice importations in 2014 at 552,000 tons of rice whereas 140.000 in the previous year 2013, that represents an increase of $8.9 \%$.

Furthermore, at the local markets, the Ndop rice instead produced by Upper Nun Valley Development Authority comes from the Northern region of the country, the Thailand, Chinese and Pakistani rice sell like hot cakes.

\section{2) Disturbing facts}

Cameroon has a lot of fertile land for rice production, according to statistics from the Ministry of Agriculture and Rural Development but the production of Cameroon is only 100.000 tons of rice which is very far below of the 300.000 tons expected demand annually. Thus, the French language news tabloid in a recent report confirmed that importation of foreign rice was also attracting foreign taxes.

The Cameroonian Ministry of Public Health $M r$. Andre MAMA FOUDA in 2014 has introduced a health inspection fee that has been literally condemned by rice importers. Moreover, a cost of $250 \mathrm{fcfa}$ was put in place per ton of rice imported in Cameroon. According to them, this method was suspicious and has been implemented to corrupt the sector.

During a board meeting of the upper nun valley development authority board meeting at Ndop a year ago, the members focus on developing strategies aimed at ameliorating rice cultivation in the institution and also mapped out ways of meeting up with the national demand.

According to the officials Agro-industrial rice production's sector, "this institution strives to maximize new perspectives by introducing the two cropping seasons". Moreover, this implies that 78.000 tons of rice production are expected in the perimeter of 14.000 hectares.

Even though there have been tremendous investments of rice cultivation in Cameroon, the country always faces high level of product demand in the sector, with less than $18 \%$ of domestic demand in the whole country. In order to understand this failure, there are various elements to be taken into consideration:

- Ineffective production cost of rainfed rice due to lack of considerable investment on raw materials and labor for an effective development of production.

- The three main production facilities are far away from the main capital cities like Douala and Yaoundé, but nearby competitive markets in other countries like Chad, Central African Republic and Nigeria which share borders with each other.

- Consumers buying behavior and preferences can't stop changing with preference, especially people from the Southern regions who are more likely to buy imported rice than domestic ones deemed inferior in terms of quality.

- The absence of domestic rice competition on other styles of rice production in the Southern Cameroon promotion of other types of rice production. Despite of new technologies the business environment has been so dynamic. The NERICA which is upland rice varieties that fit into lowland and rainfed rice production with production costs deemed minimal.
On the other hand, in the Northern region, the SEMRY project has made announcement of a rice paddy transformation machine's acquisition with the capacity of 10 tons. However, SEMRY generates an annual rice production of 78000 to 82000 tons which is eventually a massive performance. Although they pay huge taxes, they are wellknown for promoting the consumption of domestic rice in Cameroon.

Several farmers felt during the Agropastoral Commision in Ebolowa that rice was not only a source of income for the country but also a food crop that must attract the attention of all the actors of economic development. As Asangue Pius winner of the best rice farm project from the Cameroon north -west part depicted that the creation of the banks of domestic farmers could help promote by effective motivation as well as gaining access to loans to boost domestic processing and production.

\section{3) Challenges in local production}

In the rice sector across the country, there has been a decrease of investment due to the lack of investment. However, Cameroon saw a tremendous drop of rice production in the early 1990s to 62000 tons as against 70.000 tons that were harvest in 1991. At the Ndop valley, the bastion of rice production in the north- west region, some 400.900 .85 tons were produced in 1995 which constituted an insignificant output compared to the 1980 production which stood at double digit.

furthermore, there were the elimination of mechanized rice subsidies enabling great challenges in the scheme of rice production. Thus, in the early 1990's the structural adjustment plans and the CFA's devaluation put pressure on the government of Cameroon to relegate extensive. The devaluation of the Francs CFA and the structural adjustment plans in the early 1990's forced the Cameroonian government to downgrade extensive.

Farming projects. The rice sector was now in the hands of poor subsistence farmers. To meet up and satisfied the growing demand for rice, the government began engaging the importation of rice.

Due to the lack of finance, there was a failure of some agricultural projects such as SODERIM which finally shutdown. However, it has never seemed to get any easier to obtain incentives and loans to enhance production. Likewise, many farmers in the climate changes discharge all efforts while pursuing rice cultivation. Thus, the seasonal risks and loss of water have wiped out various communities in the map of rice production.

Moreover, rice's competitiveness and other important challenges to enhance productivity vary and depend on the production system in rainfed and irrigated rice cultivation.

In Cameroon, there are substantial and great capacity of rice production to develop things in the future in which the country is richly endowed for better exploitation. Despite the level of irrigated rice production that mainly focuses on areas like Northwest and Far North. It should be noted that other parts of Cameroon also have substantial capacity in the future that include:

The availability of large amounts of arable land, especially alluvial plains and lowland, mangrove areas and numerous water courses; and mangrove areas generate a high level of capacity from irrigated rice that sometimes go beyond 9 tons per hectare. Thus, At the rainfed level of production that generates more than 5 tons hectare in the lowlands is then harvested. Likewise, opportunities, policies challenges and institutional ' $\mathrm{s}$ identification to enhance food and agricultural 
production in the emergency plan proposed by the government of Cameroon in April 2008.

To gain access to producers for agricultural inputs, as well as bringing support to the production of good quality facility material recovery facility for strategic crops like support around $30 \%$ to $45 \%$ in terms of pesticides and price fertilizers for crops in specific areas.

Various techniques of price support to gain access to mechanization and supporting the cost of buying agricultural implements. gain access to mechanization through various means of price support as well as supporting the cost of buying some agricultural implements.

To improve interest rate that helps gain access to loans. It should therefore stand at $5 \%$ for middle level and small rural based companies with 9\% for agricultural holdings and Agro- industry.

To support infrastructure development that helps gain access to markets as well as establishing specific production areas with processing infrastructure and storage.

Easy access to many support services related to Agro-industry like training. However, the Cameroonian government should take remedial actions to improve rice farming and related investments and also put in effective strategies to reduce imports that slow down international trade. Such efforts deployed by government help UNDVA put in place solid perspectives to export milled rice internationally.

\section{4) Revamping the sector}

To reverse the deficit trade balance,intensified rice production will be needed and this may help to reduce the unemployment rate in Cameroon. This means government has the task to stop the importation of rice which is - was considered cheaper in the local market to concentrate on local production.

Imported rice is highly subsidized and this explains why locally produced rice seem highly costly in the local market. Local producers believe that the importation rate of rice is quite high which does not facilitate local production.

"The only remedy could be for the government to subsidize us" Mboh Mike a rice farmer remarked. Through these farmers feared that corruption could dampen the government subsidizing scheme, they opined that creating local loan schemes at community levels to finance rice cultivation could brighten the sector and their hopes. It is therefore essential for stakeholders in this sector to urge the government to boost and support farmers in the rice sector to reverse the trend.

\section{5) factors and strategies to invest in Cameroon}

\subsection{Marketing and distribution of fertilizer}

It is one of the most important conditions to ensure an effective level of production in agricultural holdings. Distribution of fertilizer and marketing give access to fertilizers.

Therefore, UNDVA's strategy is to promote capacity building for marketing fertilizers and production at the national level and enhancing the regulatory and legislative framework as well as improving the legislative and regulatory framework and ensuring its enforcement. Moreover, it is also important to find alternative techniques for mineral fertilization; and a three-year reducing subsidy for fertilizer purchases backed by the strong involvement of farmer organizations in debt recovery.

\subsection{Irrigation and investment in water control}

Due to the fact that the government is usually disengaged, there is an issue with irrigated areas that brings about water works and water's bad management. Thus, in the lowland the level of production is plagued by some issues like iron toxicity. however, the promotion of new production is very necessary in such a way that it has become vital to step into priority actions to be undertaken by UNDVA.

Moreover, it is crucial to organize and support producers to better deal with developments as well as rehabilitating the schemes of old irrigation so as to make effective ways of using infrastructures, as well as making ways for new developments. As such, this realization will be effective by taking into consideration the density of population in the area and current rice growing practices on the potential of rice by area.

Another aspect is the initiatives already put in place by farmers in regard to rice growing and development, the capacity for direct management of water by users in the design of the schemes, the need for progressive installation of irrigated areas according to user ability in their control and management, the presence of gravity-fed water and the availability of participation by local populations, the existence of several initiatives already put in place by producers, and the level of development of the private sector, especially in the field of mechanization.

\subsection{Maintenance and agricultural Equipment}

Access to appropriate production equipment and adapted processing form the pillars of promotion of middle size companies and the modernization of family holdings. Mechanization must be compatible with the technical and economic level of producers. To this effect, UNVDA will ensure capacity building for artisans and local entrepreneurs to manufacture and maintain agricultural material (small tools for land preparation, shelling machines, par boilers, stone removers, etc.). It will be also help to ensure the capacity building for maintenance of agricultural equipment as well as facilitating access by users to imported equipment through tax incentives and adapted modes of funding.

Furthermore, it is also essential to look into the capacity building for supervision of technicians with regard to agricultural mechanization; and the promotion of the role of service provider regarding maintenance of agricultural materials through the creation and equipment of pools of machines stationed in the main rice producing areas in the country.

\subsection{Support for structuring}

Support for structuring deals with skill building, extension officers and training of rice farmers by the production of data sheets for short term training in various ecologies for contact farmers or for extension officers regarding with long-term training. Likewise, the activity deals with training on the side of institutionalization and creation of rice groups of rice growers, and the support of federations, cooperatives and constitutions of unions.

Moreover, investors will then target professionalism by using effective principles of marketing and products as well as giving economic partnerships and temporary contracts between organizations of producers/rice farmers and other important actors of the industry.

Furthermore, it is important to note that Support for structuring also incorporates help to enhancing processing capacity, preparation for 
milling, capacity building, storage concerning health security in respect of the requirements of quality standards in the international, sub-regional and national markets as well as establishing ongoing data and information regarding prices and foreign and domestic markets.

\subsection{Suitable credit financing}

The absence of suitable credit financing tools has been observed at the national rice production. However, there are multiple microfinance institutions that provide loans in specific areas. Thus, supporting actions are crucial to boost financial advice taken by government in a potential framework of selective and new programs to enhance the competitiveness in family holdings. Nonetheless, it helps improve the programs of common Agricultural program and Agro-pastoral families for Africa with the missions to give advisory support to each family holding by organizations of producers with the seek for controlling effective management production and also provide financial support to investment projects of individuals by families through organizations of producers upon strategic businesses like production, support to producers, rice production by specialist advisors with good expertise in financing capacity building and profit margin generated..

Finally, it is essential for Investors to follow up economic partnerships and concentrate on new creations that are already established between actors in respect of shared costs for the operation, acquisition, equipment and works and marketing processing infrastructure, storage, packaging.

\section{SECTION 3}

\section{Concepts of research methodology}

$\mathrm{W}$ hen conducting a research, researchers carry out significant concepts in research methodology. Therefore, these concepts are very crucial in the sense that it enables the researcher to examine important elements that identify the style and research used respectively.

Conduct research at times continues to change. As such, this analysis elaborates different results and findings when the respondents have collected data.

Various concepts in this chapter will be analyzed and will be taken as exploration of the research methods as well as ideas of the discussion such as: data collection methods, research approach, research types and types of data.

Moreover, various tools which are important for analysis as well as examining the framework of the research.

Definition of research methodology ${ }^{2}$

In addition, in this methodology, all methods used may include important elements like exploration, examinations while considering present and veritable data.

\section{1) Research process onion}

In this chapter, it deals with various elements to be secured to help promote the investigation strategy [4]. When seemingly viewed, the research onion displays in detail the phase of examination process.
Besides, the appearance of the compelling movement will showcase of the research technique. Nevertheless, its presentation will analyze and display each phase of the research onion as well as giving important ideas of the research.

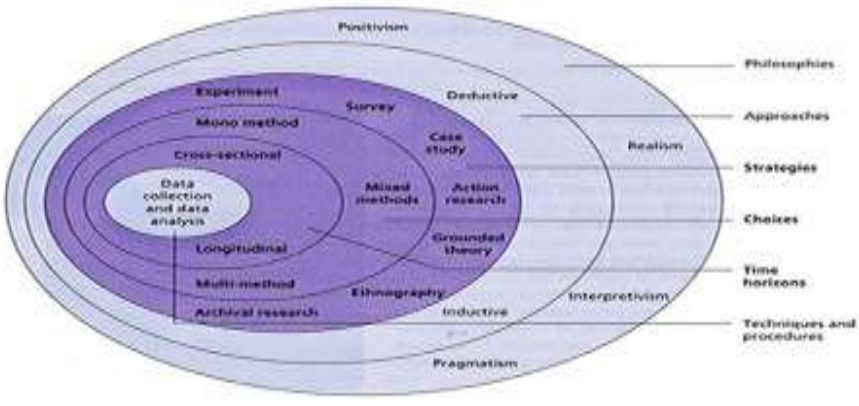

Figure 1: Research onion [5]

(It comprises and explains the six important layers of the research)

The research process onion was developed by Saunders, it deals with the evolution of the universal research that displays and contributes in order to choose the most significant data gathering techniques and enquiring techniques [6]. However, in the research process onion, there are six platforms and layers that are very crucial: approaches, strategies, times horizons, procedures and techniques described by the researcher in order to reach the peak of this work.

\section{2) Research philosophy}

Research philosophy refers to opinions and ideas by having the truth being researched. Additionally, research philosophy is seen as being basic for information [7]. Moreover, presumptions are investigated and are made by the researcher with the attempt to conduct the research. Thus, there are rationalities which differ from the ideal method and the objectives of the research that can therefore be used to achieve objectives.

The decision of the research philosophy outlines important information for the research topic. A clear understanding of the topic may result in an assumption in the process of the research as well as fitting in to methods being used. Furthermore, epistemology, ontology and axiology constitute the examination $\mathrm{s}$ independent theories.

\section{3) Research approach}

In this work, the second stratum exploration onion refers to the methodologies seen as applicable to the research. Additionally, Saunders therefore split inductive and deductive research in binary classification. 
a) Inductive research

\section{The inductive approach}

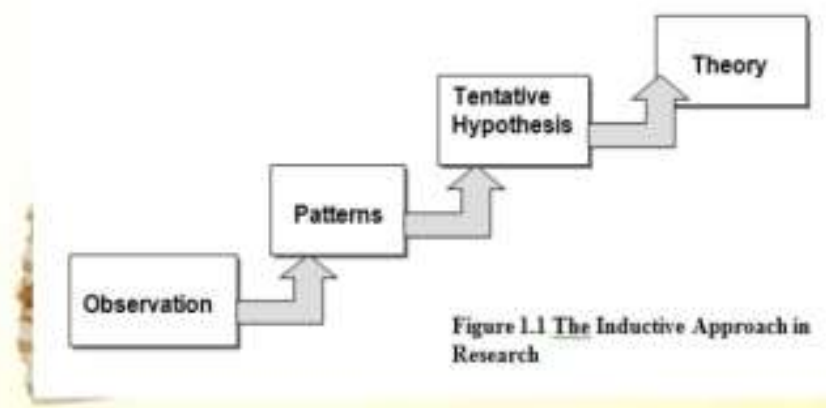

Figure 2: inductive research [8]

(It comprises theories and observations proposed in the research process)

In this research, the inductive research is outlined to begin with the itemized perceptions of the world going straight into theoretical speculations and thoughts [9]. Moreover, when conducting in inductive research, there is a tendency created by analysts based on association's recognized preparatory and also observational speculations both enabling the research to move on when choosing the research topic.

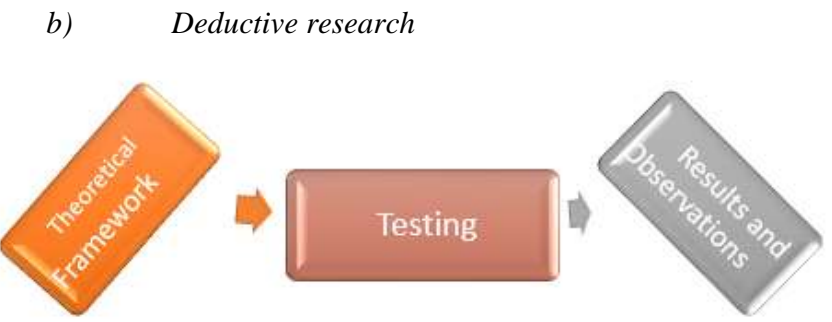

Figure 3: Deductive Research [10]

(It presents hypotheses and testing theory established in the research)

Deductive research refers to the point to where the utilization of good perceptions and the production of hypothetical structure are. In other words, it starts with hypotheses based on literature or existing knowledge as well as testing theory that are already established [11]. Therefore, important or key factors in this technique including arrangement as well as applying it as observational perceptions. Moreover, deductive research can fit in this research easily.

\section{4) Research strategies}

Research strategies are part of the research process onion. It is seen as the third layer. Therefore, in this step, significant segments are also included: exploration outlines, research system, examining methods, ideal model and information investigation that are also explored [12].
Thus, in the research process onion, the research strategies incorporate: activity, survey and contextual analysis as case study ethnography. Furthermore, research strategies in the process onion strive to examine various alternatives as well as giving a brief understanding of the survey examination chosen from the research project

Survey research.

In this part, application and analysis inquiries will help direct this research. However, this technique is considered as corporate research measure [13]. However, the statistics licenses that gather in landscape that are empirical. Thus, the bigger audience or sample size will be targeting by test mass. Subsequently, it provides to the disclosure summed up in the mid of sociological variables as well as mental.

\section{5) Research choices}

In this research, this sector is seen as the fourth element in the research process onion developed by Saunders. In addition, it displays multiple choices to be carried out, multiple method, mixed method and mono method are regarded as variables in the research choice. Thus, mono method quantitative research shall be then used [14].

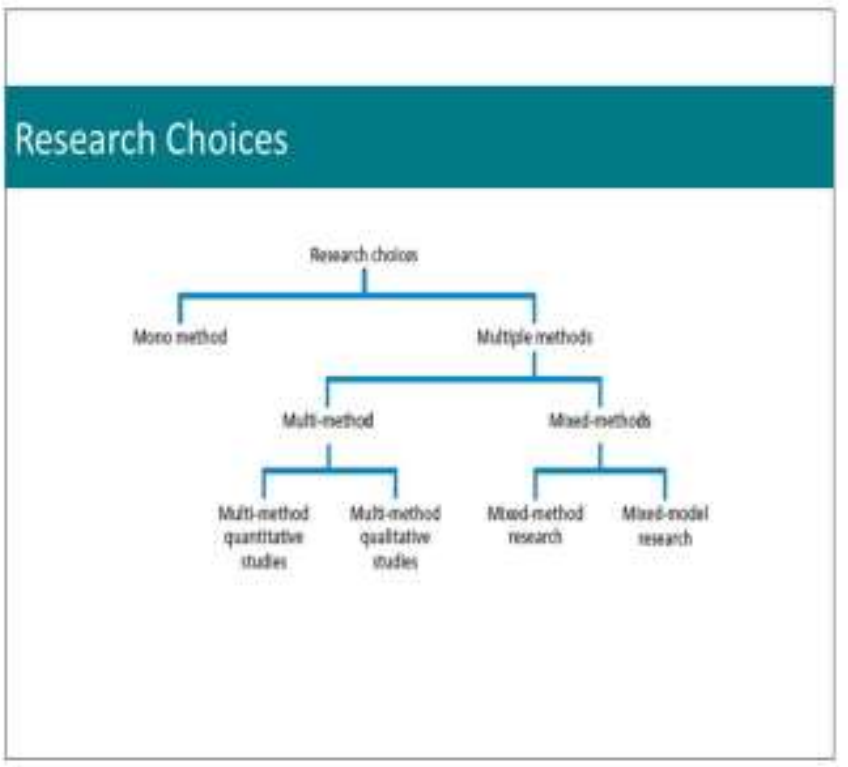

Figure 4: Research choice [15]

(It displays various choices in this research)

6) Research time horizon

There is a limited time that is imposed when investigating and conducting the research. In addition, it is regarded as the time horizon in this research [16]. Moreover, time horizon is therefore split into elements known as longitudinal and cross section. First and foremost, regarding the longitudinal, there is no need to study since there is a relative time given. Whereas, in the cross section there is a limited time imposed. Thus, the cross- sectional time horizon is therefore carried out in this investigation.
Types of research

Descriptive, exploratory Predictive,
Classification

Research purpose 


\begin{tabular}{|c|c|}
\hline Qualitative or Quantitative & Process for the Research \\
\hline basic or applied & Research outcome \\
\hline deductive or inductive & $\begin{array}{c}\text { Logic behind the } \\
\text { investigation }\end{array}$ \\
\hline
\end{tabular}

Table 2: classification types of research [17]

\section{Source: Author}

In this investigation, the most critical layer of the research onion is connected to information and investigation accumulation. In addition, in this step, choices are made to show how and the kind of information gathered, and how information are gathered and investigated as well

as their constitution. Nevertheless, multiple segments like 3.5. 3.6.3.7 Will help develop each point of analysis. Thus, in the research process onion, there are data collection.

\section{7) Conclusive research (descriptive)}

When conducting this research, conclusive research will be therefore used in the examination philosophy. Besides, researchers display important examination inquiries that are also asked. Information investigation as well as the configuration of information gathered linked with the given theme that results to problems described [18]. This kind of exploration constitutes the quantitative and methods of subjective research.

\section{8) Quantitative research}

In this research, the best alternative is choosing research method that fits in the process of this research. However, in nature, the examination will be factual and numerical, quantitative research will be therefore used [19]. Thus, it uses definitions and specific ramifications as well as variables along with measures given variables, examined factual and numerical [20].

\section{Types of data/ classifications}

\section{9) Secondary data}

In this investigation, information gathered by office and people will be used as secondary information. Additionally, the sample of such data is regarded as a study which is carried out by administration division based on family nourishment [21]. In other word, a sustenance maker may use specific information as back up while assessing important business areas. Thus, auxiliary's information is made up of: financial data, transport data, sales data and storage data.

\section{0) Primary data}

The sources of essential data are the types of gathered and watched information obtained from the first experience [22]. In addition, the sources of essential information are also ranked under subjectivity and quantitative counting on the researcher that carries out the research. Furthermore, the source of primary data incorporates: paintings, photographs, stories and histories.

\section{1) Data collection method - questionnaire}

In this investigation, as information have been gathered already, it is very crucial to use survey. Therefore, having different variables and survey planning might become a bit confused. In this case, the poll should be taken into consideration while compelling all variables [23]. marketing and distribution of fertilizer, irrigation and management of water control, maintenance and machinery equipment, support for structuring and suitable credit financing- as well as studying the impact of Agro industrial rice cultivation, case study of the challenges facing rice farmers in UNVDA, Cameroon.

\section{2) Research procedure}

When conducting a research, it is an important element of actions. In order to develop a topic, research procedure is a crucial element for investigation with the aim of making it easier with experience.

\begin{tabular}{|l|l|}
$\begin{array}{l}\text { (Months) } \\
\text { Timelines }\end{array}$ & Procedure \\
\hline June 2018 & Define the research problem \\
\hline June 2017 & Preparation of the research proposal \\
\hline June 2017 & $\begin{array}{l}\text { Preparing the introduction and literature } \\
\text { review }\end{array}$ \\
\hline July 2018 & Constructing instrument for data collection \\
\hline July 2018 & Sample selection \\
\hline July 2018 & Data collection \\
\hline August 2018 & Analysis and statistics \\
\hline August 2018 & Interpreting data \\
\hline August 2018 & Findings, discussion of interpretation \\
\hline August 2018 & Recommendations and conclusions \\
\hline
\end{tabular}

\section{Table 3: research procedure}

\section{Source: author}

(it indicates the management of time throughout the research) When conducting the research, there is a survey given to respondents containing relevant questions that help investigate the impact of Agro industrial rice cultivation, case study of the challenges facing rice farmers in UNVDA, Cameroon.

Therefore, in the first part, there will be the identification of questions personal information like gender, age, information channels, rules and regulations of Cameroon and income level will be analyzed. In this step, the questions are simple and enable the respondents to understand easily.

In this part, there are relevant questions about the impact of Agro industrial rice cultivation, case study of the challenges facing rice farmers in UNVDA, Cameroon. In such case, these questions are designed in points by using linear scale and yes, no and moderately questions. Likert scale was also used in this part to enable the respondents circle the answers.

\section{3) Statistical methods}

It refers to the analysis of numbers and calculating the results of quantitative data. In addition, data are classified. As such, in order to interpret and analyze data, there is the use of statistical programs. Furthermore, to interpret data, frequency statistic is then used. In this case, having crucial elements become important

\section{Profile of respondents}

In order to conduct this investigation on the impact of Agro industrial rice cultivation, case study of the challenges facing rice farmers in UNVDA, Cameroon. will be elaborated. In this research, 50 questionnaires will be distributed to the respondents. Thus, the target respondents are generally from Cameroon who are all employees. The target respondents involved in this research are female and male. 
Target respondents, sampling, sample size

In this research, it would be significant to base targets respondents. Therefore, in the primary point, this stage has important factors to gather information testing, measurably speaking to the people as well as influencing the research. About quantitative research, there is critical case on the sample due to numerical quality that can be used to understand the connection between autonomous and subordinate variables. However, as a sample there will be a practical case of 50 respondents to be used so as to come up with satisfactory result that will sum up the entire population.

Moreover, non- probability refers to testing strategy meanwhile a few factors of respondents deliberately has no access to make choice. Additionally, in this stage the likelihood of engagement is not yet to decide. Nevertheless, it constitutes various choices of components with the view of suspicion on the number of inhabitants in interest which also constitute multiple criteria for that determination [24]. As such, that determination of elements is therefore regarded as non- random. Non-probability testing does not go in accordance with the estimation examining blunder. Besides, auditions spot slows down the total data. As such, the population becomes restricted at the test s middle which does not facilitate any deduction from sample to population [25].

\begin{tabular}{|l|l|}
$\begin{array}{l}\text { Research } \\
\text { Method }\end{array}$ & \multicolumn{1}{c|}{ Technique } \\
\hline Methodology of the research & Descriptive (Conclusive) \\
\hline Method of Data Collection & $\begin{array}{l}\text { Primary Data and secondary } \\
\text { data }\end{array}$ \\
\hline Instrument of the research & $\begin{array}{l}\text { A survey is conducted with } \\
\text { sample size of 50 respondents } \\
\text { amongst young adults in } \\
\text { UNVDA, Cameroon }\end{array}$ \\
\hline Target Respondents & $\begin{array}{l}\text { Agro -industrial rice cultivation } \\
\text { Employees between 31-50 and } \\
\text { above }\end{array}$ \\
\hline
\end{tabular}

\section{Table 4: table of resources}

\section{Source: Author}

\section{4) Considerations and research credibility}

When investigating or conducting a research, it is very significant to assure the validity of each system and investigation. Saunders has developed the imperative contemplations that are: legitimacy, false presumptions, generalizability, dependability and natural jumps [26]. However, accumulating information is also important when using strategies, dependence

And sources. Moreover, information ought to be substantial and generalized for subgroups as well as applicable gatherings.

\section{5) Challenges and limitations of the research}

In the research, gathering important information can be affected by the predisposition of respondents. Information can also be influenced by legitimacy and also the polls left of the writing. Therefore, factors resulting to changes in finance, politics, and social as well as other elements on daily basis [27]. Furthermore, the absence of information learning variables in Douala. Nonetheless when failing in nature, information research keeps up with respect and ends up having positive effect on the elucidation and results findings. Thus, the oversight becomes purposeful and unexpected, the human slip and likelihood meanwhile the sample size is vast.

\section{6) Ethical considerations}

When carrying out a research, the analyst and member should follow the code of morality. A representation should be there to make good qualities and adequate choices, with ethics and qualities that include important element [28].

\section{7) Informed consent}

In this research, the respondents intend to have pertinent data deemed important to them. for instance, this can therefore happen when providing data which are upgraded to members in order to better understand the research [29].

\section{8) Beneficence}

A research or exploration should be done to allow the specialist consider physical members and mental well-being. Therefore, data or activity that expose members to risks that will be then rejected.

\section{9) Anonymity and confidentiality, privacy}

To better analyze this research, it would be significant to consider the respondent s secrecy unless the respondent is consent. Nevertheless, the respondents will be regarded.

\section{0) Adherence to regulations laws and rules}

The investigator therefore acts in the confines of national, regulations, institutions. The law of West Cameroon will be abided at every institution s guideline

3-18 Prejudices and biases

Personal biases and prejudices in this research are avoided in order not for the researcher to get affected. In this exploration, the researcher will assure the integrity of the examination in various elements involved. Thus, the importance of data collection while using scientific and empirical observation.

\section{1) Conclusion:}

in this chapter, it was important to come up with the research design and methods. Therefore, quantitative methods will help the research analyze and interpret the data.

\section{V.SECTION 4}

Interpretation of data analysis

Question 1: Gender 


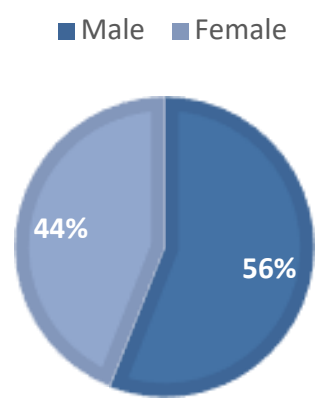

Figure 5: Gender of the Respondents

Source: Author

\begin{tabular}{|c|c|c|}
\hline Mumber of Respondents & Percentage \\
\hline Female & 28 & $56 \%$ \\
\hline Total & 22 & $44 \%$ \\
\hline
\end{tabular}

Table 5: Frequency of gender

Source: Author

Interpretation and analysis

G ender refers to the state of being female or male. However, in this Jinvestigation, it deals with the sex of all participants. Therefore, there are 28 respondents falling under male that represent a percentage of $56 \%$. whereas there are 22 respondents falling under female that shows the percentage of $44 \%$. From this interpretation, majority of respondents were male that depicts that male have more participated in this survey than female. From this perspective, it is clear that there is a long -standing history between male in the Agro industrial rice sector and such opportunity can be seen as a potential workforce and target market for foreign investors.

\section{Question 2: Age}

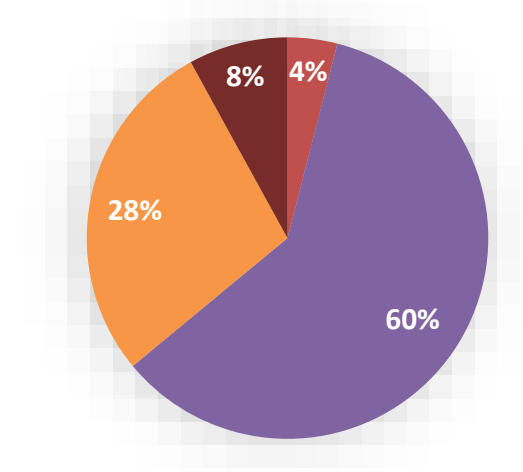

-21 - 30 -31 - $40 \square 41-50 \square 51$ and above
Figure 6: Age of the Respondents

Source: Author

\begin{tabular}{|c|c|c|}
\hline & Number of Respondents & Percentage \\
\hline $\mathbf{2 1}-\mathbf{3 0}$ & 2 & $4 \%$ \\
\hline $\mathbf{3 1}-\mathbf{4 0}$ & 30 & $60 \%$ \\
\hline $\mathbf{4 1}-\mathbf{5 0}$ & 14 & $28 \%$ \\
\hline $\mathbf{5 1}$ and Above & 4 & $8 \%$ \\
\hline Total & 50 & $100 \%$ \\
\hline
\end{tabular}

Table 6: Age Frequency

Source: Author

Interpretation and analysis

From this interpretation, the highest classification of age felt under 3140 with 30 respondents and $60 \%$ frequency. The second highest classification felt under 41-50 with 14 respondents and 28\%. The third highest classification felt under 51 and above with 4 respondents and $8 \%$ frequency. And finally, the last classification felt under 2 respondents with $4 \%$ frequency.

The figure of age's statistic clearly displays the Cameroon's best ranking segmentation of age for Agro industrial rice production. From this perspective, foreign investors should mainly concentrate upon people especially adults of 31-40 to carry out their operations.

Question 3: What are the major problems faced by rice farmers in adopting pre and post -harvest management techniques?

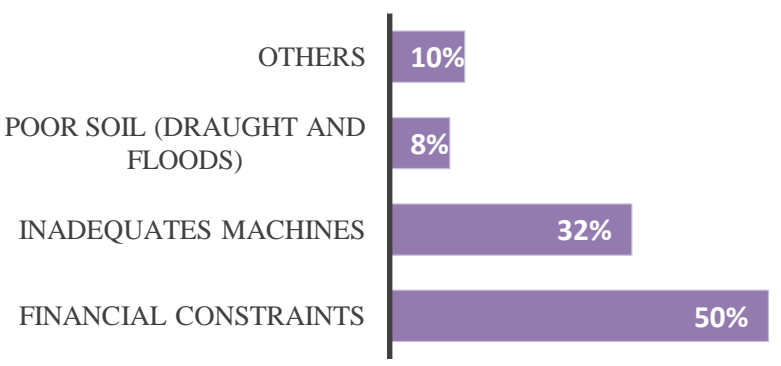

Figure 7: Problems faced by farmers

Source: Author

\begin{tabular}{|c|c|c|}
\hline & Number of respondents & Percentage \\
\hline Financial Constraints & 25 & $50 \%$ \\
\hline Inadequate Machines & & \\
& 16 & $32 \%$ \\
\hline Poor Soil & & \\
\hline Others & 4 & $8 \%$ \\
\hline
\end{tabular}




\section{Total} 50

Table 7: Frequency of the respondents

Source: Author

Interpretation and analysis

From this interpretation, the highest numbers of respondents felt under financial constraints with 25 respondents and $50 \%$ frequency. The second highest result felt under inadequate machines with 16 respondents and 32\% frequency. The third highest result felt under 5 respondents with 5 respondents and $10 \%$ frequency and the last result felt under 4 respondents and $8 \%$ frequency. From this analysis foreign investors should analyze and identify the sources of these problems in the sector and take immediate actions.

Question 4: What are the management techniques employed by companies to reduce pre and post-harvest losses?

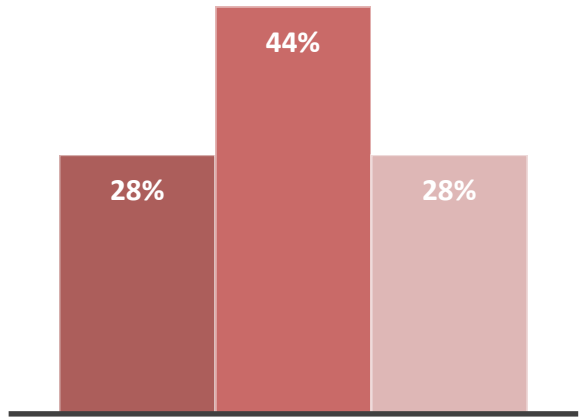

- Increase Productivity

- Land Development

Mrovision of farm inputs

Figure 8: Management Techniques

Source: Author

\begin{tabular}{|c|c|c|}
\hline & $\begin{array}{l}\text { Number of } \\
\text { respondents }\end{array}$ & Percentage \\
\hline Increase Productivity & 14 & $28 \%$ \\
\hline Land Development & 22 & $44 \%$ \\
\hline $\begin{array}{c}\text { Provision of Farm } \\
\text { Inputs }\end{array}$ & 14 & $28 \%$ \\
\hline Total & $\mathbf{5 0}$ & $\mathbf{1 0 0 \%}$ \\
\hline
\end{tabular}

Table 8: Frequency of the Respondent

Source: Author

Interpretation and analysis

In this investigation, the interpretation just mentioned above clearly depicts that land development has the highest number of respondents with 22 respondents and the frequency of $44 \%$. The second highest result is increase productivity and provision of farm inputs with both 14 respondents and $28 \%$ frequency, and the third highest.

Question 5: What are the UNVDA's causes of losses at the post Harvesting Stage?

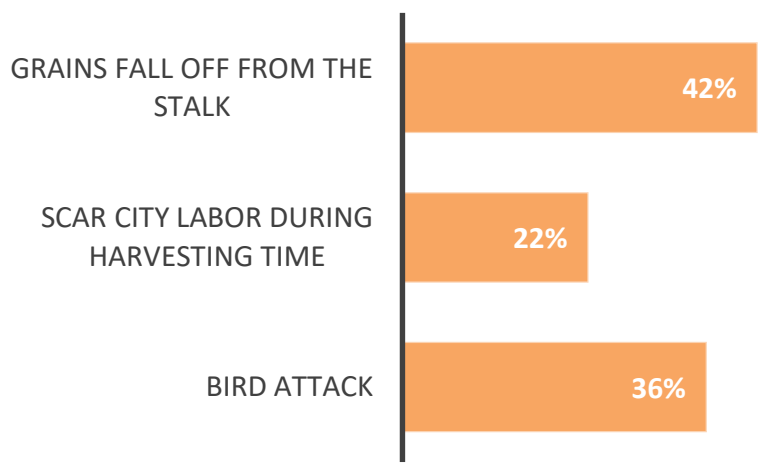

Figure 9: Causes of losses

Source: Author

\begin{tabular}{|c|c|c|}
\hline Bird Attack & $\begin{array}{c}\text { Number of } \\
\text { respondents }\end{array}$ & Percentage \\
\hline $\begin{array}{c}\text { Scar city labor during } \\
\text { harvesting time }\end{array}$ & 18 & $36 \%$ \\
\hline $\begin{array}{c}\text { Grains fall off from the } \\
\text { stalk }\end{array}$ & 21 & $22 \%$ \\
\hline Total & 50 & $42 \%$ \\
\hline
\end{tabular}

Table 9: Frequency of Respondents

Source: Author

Interpretation and analysis

From this interpretation, the highest number of respondents felt under grain fall off from the stalk with 21 respondents and the frequency of $42 \%$. The second highest number is 18 respondents with $36 \%$ frequency and the third is scarcity labor during harvesting time with 11 respondents and $22 \%$. From this analysis, the analysis of this problem will enable foreign investors come up with new strategies to solve these problems. 


\section{International Conference on Academic Research in SCIENCE, TECHNOLOGY and ENGINEERING}

Question 6: Are Government policies favorable to foreign investors in Cameroon?

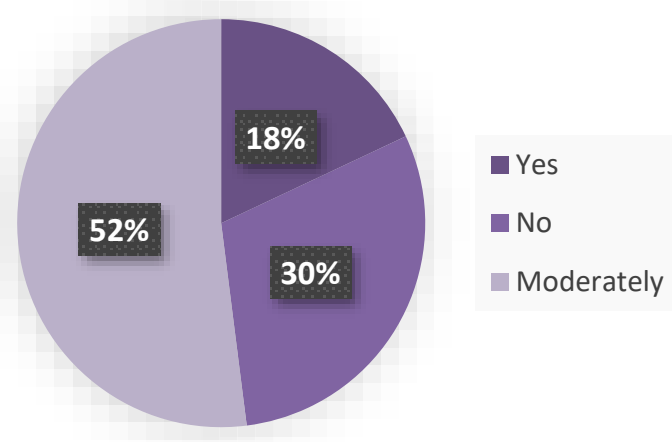

Figure 10: Government's rules and regulations

Source: Author

\begin{tabular}{|c|c|c|}
\hline & Number of respondents & Percentage \\
\hline Yes & 9 & $18 \%$ \\
\hline No & 15 & $30 \%$ \\
\hline Moderately & 26 & $52 \%$ \\
\hline Total & 50 & $100 \%$ \\
\hline
\end{tabular}

Table 10: Frequency of Respondents

Source: Author

Interpretation and analysis

From this interpretation, 26 respondents answered moderately with the percentage of $52 \%$. The second highest result is no with 15 respondents with $30 \%$ frequency, whereas the last result is yes with 9 respondents and the percentage of $18 \%$. From this analysis, rules and regulations in Cameroon for most of respondents is accessible to foreign investors. However, the government of Cameroon to boost the Agro - industrial rice sector should encourage foreign direct investment which can be benefit to boost the economy smoothly.

Question 7: Is Income level of sellers on local rice production good enough to attract investors?

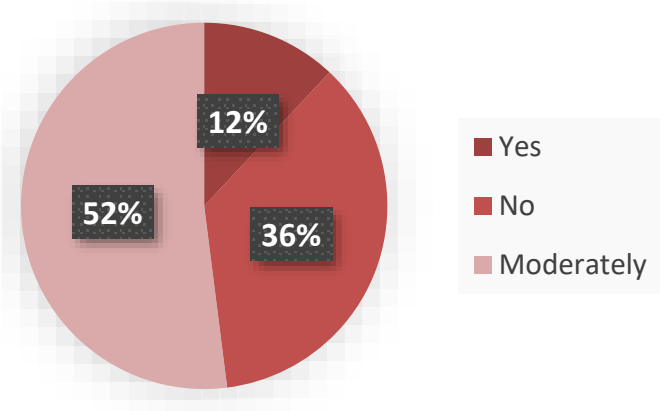

Figure 11: Income level of sellers

\begin{tabular}{|c|c|c|}
\hline & Number of respondents & Percentage \\
\hline Yes & 6 & $12 \%$ \\
\hline No & 18 & $36 \%$ \\
\hline Moderately & 26 & $52 \%$ \\
\hline Total & 50 & $100 \%$ \\
\hline \multicolumn{2}{|r}{ Table 11: Frequency of Respondents }
\end{tabular}

Source: Author

Interpretation and analysis

From the table just mentioned, 26 respondents answered moderately with $52 \%$ frequency. And the second highest number answered no with 18 respondents and 36\% frequency. The third highest number answered yes with 6 respondents with $12 \%$ frequency.

Question 8: Do Consumers buying behavior affect sellers towards the purchase of rice in Cameroon?

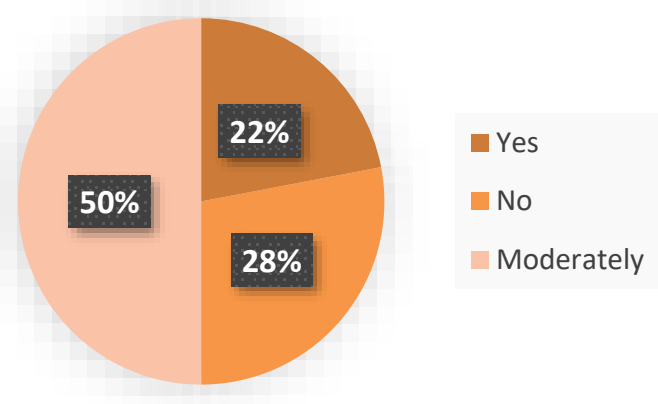

Figure 12: Consumer buying Behavior

Source: Author

\begin{tabular}{|c|c|c|}
\hline & Number of respondents & Percentage \\
\hline Yes & 11 & $22 \%$ \\
\hline No & 14 & $28 \%$ \\
\hline Moderately & 25 & $50 \%$ \\
\hline Total & 50 & $100 \%$ \\
\hline
\end{tabular}

Table 12: Frequency of Respondents

Source: Author

Interpretation and analysis

From the circle and table just mentioned above, 25 respondents answered moderately with $50 \%$ frequency. The second highest number is 14 respondents and the frequency of $28 \%$. The third number of respondents is 11 respondents with $22 \%$ frequency.

Question 9: Is the business environment currently stable in Cameroon? 


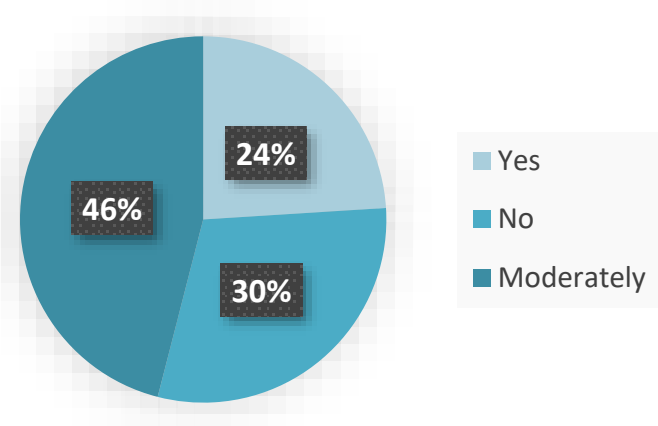

Figure 13: Business Environment

Source: Author

\begin{tabular}{|c|c|c|}
\hline & Number of respondents & Percentage \\
\hline Yes & 12 & $24 \%$ \\
\hline No & 15 & $30 \%$ \\
\hline Moderately & 23 & $46 \%$ \\
\hline Total & 50 & $100 \%$ \\
\hline
\end{tabular}

Table 13: Frequency of Respondents

Source: Author

Interpretation and analysis

From the information mentioned above, 23 respondents answered moderately with $46 \%$ frequency. Whereas the second number of respondents is no with 15 respondents and the frequency $30 \%$ and the final number of respondents is 12 with $24 \%$ of frequency.

Question 10: Can you suggest investors to run their business in the Agro - industrial rice sector in Cameroon?

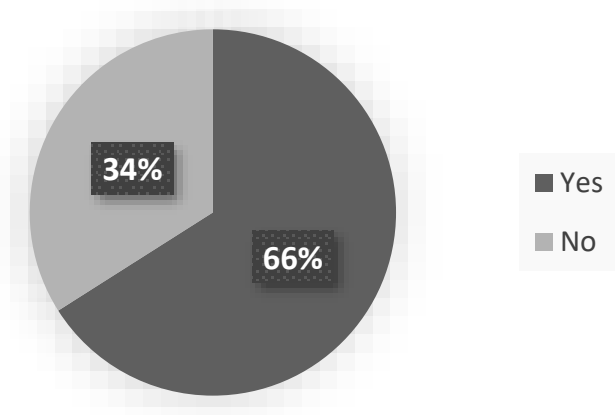

Figure 14: Suggestion

Source: Author

\begin{tabular}{|c|c|c|}
\hline & Number of respondents & Percentage \\
\hline Yes & 33 & $66 \%$ \\
\hline No & 17 & $34 \%$ \\
\hline Total & 50 & $100 \%$ \\
\hline
\end{tabular}

\section{Table 14: Frequency of Respondents}

\section{Source: Author}

Interpretation and analysis

From the interpretation just mentioned, the highest number of respondents is yes 33 respondents with $66 \%$. Whereas the second number of respondents is 17 with the frequency of $34 \%$.

\section{SECTION 5}

\section{Recommendations and conclusion}

Tn this research, in order to have a better understanding of the impact of Agro-industrial rice cultivation, the researcher makes analysis and interpretation. Moreover, the sector of Agro -industrial rice cultivation is a growing economic sector that contributes to growth in the national sector as well as international level.

\section{1) Conclusion}

In this research study, the conclusion helps determine important finding elaborated in the form of discussion in each of the research objectives. Based on the interpretation and analysis of data. There is a positive or significant evidence that demonstrate that each factor in the research objective was elaborated to influence Agro industrial rice production.

- To analyze how marketing and distribution of fertilizer affect Agro industrial rice cultivation in UNVDA, Cameroon.

- To illustrate how irrigation and investment in water control affect Agro industrial rice cultivation Sa Cameroon.

- To determine how maintenance and agricultural equipment affect Agro industrial rice cultivation in UNVDA, Cameroon.

- To elaborate how support for structuring the effects of harvesting affect Agro industrial cultivation in UNVDA Cameroon.

To investigate how suitable credit financing affects Agro industrial rice cultivation in UNVDA Cameroon.

\section{Research objective 1 marketing and distribution of fertilizer}

In this investigation, the objective of marketing and distribution of fertilizer was met in chapter 2 by the literature review that concluded that marketing and distribution of fertilizer is crucial as it ensures the capacity building for production and marketing of fertilizer, it also ensures an appreciable increase in yields in the productivity of agricultural holding as well as improving the legislative and regulation framework and ensures its enforcement. However, foreign investors who strive to invest in Cameroon in Agro- industrial rice sector should continue studying, analyze and understand cultural factors in order to meet the need of consumer.

By adapting to the Cameroon's culture, norms, attitudes and wellness to consumers, looking up to the region side, understanding the local language by improving the means of communication, as well as knowing advertising preferences, foreign investors will see significant growth in the future.

In summary, the researcher has provided the findings with a clear understanding of how distribution and marketing of fertilizer is able to influence Agro -industrial rice cultivation in Cameroon. 


\section{Research objective 2: irrigation and investment in water control}

In this investigation, the objective of irrigation and investment control was met in chapter 2 when the researcher conducted the literature review that concluded that irrigation and investment in water control are essential as management development and the rehabilitation of old irrigation schemes are used, and the need for progressive of irrigated areas according to user ability in management control. As such, foreign investors should analyze and understand consumer's perceived quality so as to satisfy their needs and build customer's loyalty. Therefore, as such, companies should strongly deliver safety and provide additional features. They should provide unique value proposition to attract more customers and reduce their customer's complain list.

\section{Research objective 3: maintenance and agricultural equipment}

In this research, the objective of maintenance and agricultural equipment was met in chapter 2 when the researcher conducted the literature review that concluded that it is essential as it ensures the capacity building for maintenance of agricultural equipment, it ensures the capacity building for artisans and local entrepreneur to manufacture as well as maintaining agricultural materials. Therefore, foreign investors should understand key elements in marketing such as adding a unique value proposition by clearly stating what they do, how they do it, and who they do it for. Thus, a unique value proposition will set the business apart from other competitors.

\section{Research objective 4: support for structuring}

In this investigation, the objective of social factors was met in chapter 2 when the researcher conducted the literature review that concluded it is important as it helps contribute to the necessity support for marketing as well as developing temporary contracts and other economic partnerships between rice farmers/producers and other important actors of the rice sector. Therefore, foreign companies should identify what they are trying to fulfill by therefore engaging with all influencers. In addition, the company should also pinpoint metrics they actually strive to use in order to know how much progress they have achieved towards fulfilling their goals.

Research objective 5: suitable credit financing

In this research, the objective of personal factors was met in chapter 2 when the researcher conducted the literature review that concluded that it is important as it provides financial support to groups and individual investment projects owned by families and by producers of companies on business strategies of rice production. It also provides advisory's support to producers in the company through specialist advisors with expertise in funding profit, generating activities and capacity building.

\section{further research}

In summary of this research, Agro - industrial rice cultivation, case study of the challenges facing rice farmers in UNVDA is affected by factors such as marketing and distribution fertilizer, irrigation and investment in water control, maintenance and machinery equipment, support for structuring and suitable credit financing. In today's business, managers can easily understand the essence of this research. However, this investigation can even go further since the current business environment continuously changes with new trends. The advancement of technology and globalization and the dynamism of the current market make companies keep up with the latest. Thus, it becomes important and crucial to organizations to adapt to these changes, and this can be used by using important concepts and strategies that will enable marketing managers achieve their objectives.

\section{Acknowledgement}

All my profound gratitude to my supervisor CHRISTIAN ATANGANA who took keen interest on this work project. extremely thankful To my classmate for providing such a nice guidance and support.

big thanks to my wife OKON for her support and encouragement.

\section{REFERENCE}

[1] UNVDA, "GRIN," UNVDA, Vols. 3-9, no. Value Chain, pp. 36-40, 2012.

[2] UNVDA, "Growing Rice Production in Cameroon," Academic Texts journal, vol. 7, pp. 112-121, 2011.

[3] C. Tribune, "Ndop Rice Production," Cameroon Tribune, vol. 4, pp. 16-17, 2012.

[4] Thornwill, How to Conduct a Research, 3rd ed., Denver: Sage Publications, 2012.

[5] Saunders, Research Methods in Business, 4th ed., London: Prendice Hall, 2011.

[6] Willinger, Study of Research Methods and Conceptual Framework, 3th ed., Dallas: Prendice Hall, 2012.

[7] Lennon, Business Philosophy In Research Methodology, 4th ed., Stuttgart: Prendice Hall, 2008.

[8] M. Prince, Social Research Methods, Quantitative and Qualitative Research, 2nd ed., Chicago: Allyn and Bacon, 2011.

[9] Stephen, Social Research Methodology and Quantitative Research, 2nd ed., Chicago: Allyn and Bacon, 2011.

[10] Saunders, Business Research Methods and Guidelines for research Methodology, 3rd ed., London: Prendice Hall, 2009.

[11] Saunders, "Reseach Methodoly and Conceptual Framework," Journal of Cultural aspects and International Policies, vol. 16(2), no. 1, pp. 330-343, 2009. 
[12] Neumann, "Analysis Force Field and Leardership as tools for Planning," Leadership and Organizational Development, vol. 29, no. 7/3, pp. 147-182, 2013.

[13] A. Mark, Survey Business Research, 3rd ed., Dublin: Sage Publications , 2011.

[14] Webster, Qualitative Method Research, 3rd ed., Dallas: Prendice Hall, 2011.

[15] Saunders, Research Choices and Guidelines for Business Students, 2nd ed., Liverpool: Prendice Hall, 2011.

[16] Lewis, Conducting Research Methods for Business Methods, 3rd ed., Oklahoma: Prendice Hall, 2007.

[17] H. Roger, Theoretical Framework for Graduates and Postgraduates Students, 3rd ed., Johannesburg: Mc Milan, 2008.

[18] D. Earl, Social Research and Environmental Practices, 3rd ed., Oslo: Cengage Learning, 2012.

[19] Andrew, "Research Qualitative and Quantitative Methods," Geo, Ceo Imperial, Stockholm, 2008.

[20] Cooper, "Applying Quantitative and Qualittative in Organizational Culture," Theory and Applied Systems of Communication, vol. 18, no. 3, pp. 90-98, 2009.

[21] Steven, "Conducting a Research and Relevance of Information," Harvard Business Review, vol. 8 (4), no. 4th, pp. 62-74, 2011.

[22] Sapstord, Analysis and Data Collection, 3rd ed., New Jersey: Sage Publications, 2013.

[23] Mohamed, Typical Guidelines for Students: Experience and Methods of data collection, 3rd ed., Leeds: New Dawn, Press Group, 2011.

[24] Zuma, "Survey Research; How to elaboarate accurate sample size," Learning and Performance, Information Technology Journal, vol. 16 (3), no. 3rd, pp. 65-83, 2004.

[25] Fen, "Sample Mixed with Typical Methods," Journal of Mixed Approach, vol. 5(3), no. 2, pp. 79-97, 2013.

[26] Philips, Conducting and Guiding students in Research Methods, 3rd ed., Manchester: Sage Publications, 2010.

[27] Wills, Conducting and Learning Research Methods, 2nd ed., Melbourne: Prendice Hall, 2004.

[28] William, "Opportunities and Value Creations in the Development of Technical Industry," Atkeaney, Geneva, 2014.

[29] Clark, "Personality Psychology and analysis of cognitive tasks," Harvard Business Review, vol. 40, no. 1, pp. 365-380, 2010. 